\title{
Application for Calculation of Islamic Sharia Inheritance Based on Android for Mawaris Fiqh Courses
}

\author{
Artesia Anwar $1{ }^{1,}$ Gusnita Darmawati \\ ${ }^{1,2}$ Informatics and Computer Engineering Education IAIN Bukittinggi, Bukittinggi, Indonesia
}

\begin{tabular}{l} 
Article Information \\
\hline Article History: \\
Accepted by Editor: November 05, 2021 \\
Final Revision: December 16, 2021 \\
Published Online: December 31, 2021 \\
Keywords \\
\hline Legacy \\
Android \\
R\&D \\
4D \\
Waterfall \\
Correspondence \\
\hline E-mail: artesiaanwar73@gmail.com*
\end{tabular}

E-mail: artesiaanwar73@gmail.com*

\section{A B S T R A C T}

This research was motivated by the discovery of problems in terms of calculating inheritance in the Mawaris Fiqh course at the Islamic Family Law Department of IAIN Bukittinggi, the calculation of inheritance in the Maris Fiqh course still uses the manual method, in which lecturers and students still have to calculate using pen and paper how much the number of shares of each person entitled to inheritance rights. The purpose of this research is to design an Android-Based Application for Inheritance Calculation of Islamic Law for Fiqh Mawaris Subject, Islamic Family Law Department, Sharia Faculty IAIN Bukittinggi, which is practical, effective and efficient. The method used in this research is Research and Development, better known as (R\&D). 4D Models (Define, Design, Develop, Disseminate). The system development model used is the System Development Life Cycle (SDLC). The model used in this SDLC is the waterfall, namely Communication, Planning, Modeling, Construction, and Development. The programming language used is the PHP programming language. The product test used is the Test of Validity, Test of Effectiveness and Test of Practicality. The system that has been designed has been tested and has been declared valid, effective and practical in its use. The results of the product test that the author did obtain a validity test from 3 experts obtained a value of 0.80 with a valid category, a practicality test from 5 practitioners obtained a value of 0.93 in a very high category, and test effectiveness of 5 appraisers obtained a value of 0.86 effective categories.

This is an open access article under the CC-BY-SA license

\section{Introduction}

IAIN Bukittinggi, is one of the Islamic State University, which is developing in Bukittinggi. Until now it has thousands of students who are growing rapidly from year to year. This institute consists of several faculties, one of which is the Faculty of Sharia (FSYAR), one of the study programs at FSYAR is Islamic Family Law (HKI). The Study Program is a part that has important facilities to obtain useful information for students in the lecture process, one of which is learning about the calculation of inheritance in the family in the Mawaris Fiqh course [1].

Inheritance, means the transfer of something (both material and non-material) from one person to another. This heritage is rooted in the word Al-Irts or Al-Mirats. Meanwhile, according to the term inheritance is fara'id (relic), inheritance is property in the form of money or valuables where the inheritance is a relic of someone who has died. Those who are entitled to receive the property/inheritance left behind are called heirs [2]. 
To determine how the distribution of inheritance to be distributed to the heirs is discussed in a topic study called Fiqh Mawaris. If the owner of the property has died, the property will be transferred to the heirs called the Mawaris. Hasby Ash-Shiddieqy stated that inheritance law regulates the ways and rules regarding the distribution of inheritance left by the deceased to the heirs and those who are entitled to the inheritance [3].

For now, the science that studies the calculation of inheritance is slowly being forgotten, because calculating the amount of inheritance is quite complicated. This makes students confused enough to be less interested in studying this topic.

As time goes by, slowly Muslims have started to forget, even no longer learn the science of this Mawaris. Including students in this department, who also have difficulty understanding this field of science, become less interested in learning it. Even though the law of Mawaris is needed especially to maintain relations between families. Not a few families who broke up just because of misunderstanding and ignorance of this Mawaris law.

The lack of people who have knowledge and understanding of faraid science causes Mawaris science to be not widely known to the public, especially the santri, where this knowledge is very important to know [2]. Therefore, the author wants to make an application for calculating inheritance according to Islamic law, based on Android using the PHP programming language to help students make it easier to learn and calculate the distribution of inheritance. Students can apply and teach this knowledge to their families and communities.

Android is an operating system based on Linux where the operating system can be used both on smartphones and personal computers that are open source, with that application development companies can easily and quickly develop applications that will be made to be installed on the system. This operation is the operating system with the most users worldwide [4]. Because it is open source, developers are very flexible in developing applications that will be applied to an Android-based operating system, including this Faraid application. Faraid is property in the form of money or valuables left by people who have died [5].

\section{Method}

This study uses the Research and Development method. Research and Development (R\&D) is a process to produce and develop a product which is carried out in several stages [8]. For this reason, in making products, you must attach a report and be equipped with documentation and attachments, explanations, and product specifications produced.

Dalam In this study the author uses the R\&D development model version 4D (Four D) that developed by Thiagarajan in 1974, such as; define, design, develop, disseminate (definition, design, development and trial) [6]. The reason for choosing this version of the model is because this model is suitable for use in the research that the author is doing, focus on product manufacturing. This model also makes it easier for writers to manufacture and develop products because each activity is carried out sequentially to calculate inheritance according to Islamic law in the Mawaris fiqh course.

The stages and also the sequence of each step in this method are shown in Figure 1 below [7].

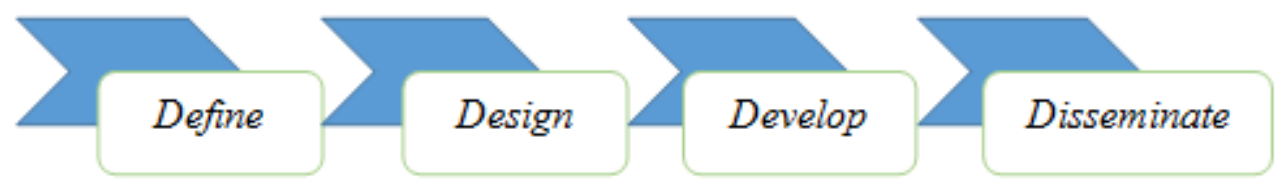

Figure 1. 4D Stage

The system development model used in this research is the Software Development Life Cycle (SDLC). In general, the SDLC is divided into three activities, namely the first analysis stage, the second the design stage 
and the third is the implementation stage, the SDLC itself is a process in which software is updated and also developed based on the methodology and also the stages and steps measures used from previous studies [8].

SDLC has several models in the application of the stages of the process. From several existing models, the author applies the waterfall model. According to Pressman, the waterfall model is used in making a product or software sequentially or systematically. So that in its manufacture it must be used in stages and carried out sequentially.

There are several advantages of the waterfall model, namely, the implementation and the process is carried out sequentially, making it easier for the user to prepare and also plan all the needs in carrying out the stages in making the product, the schedule for each stage can be planned and carried out with certainty [9].

In Figure 2 below, we can see how the shape and stages of the waterfall model are [10].

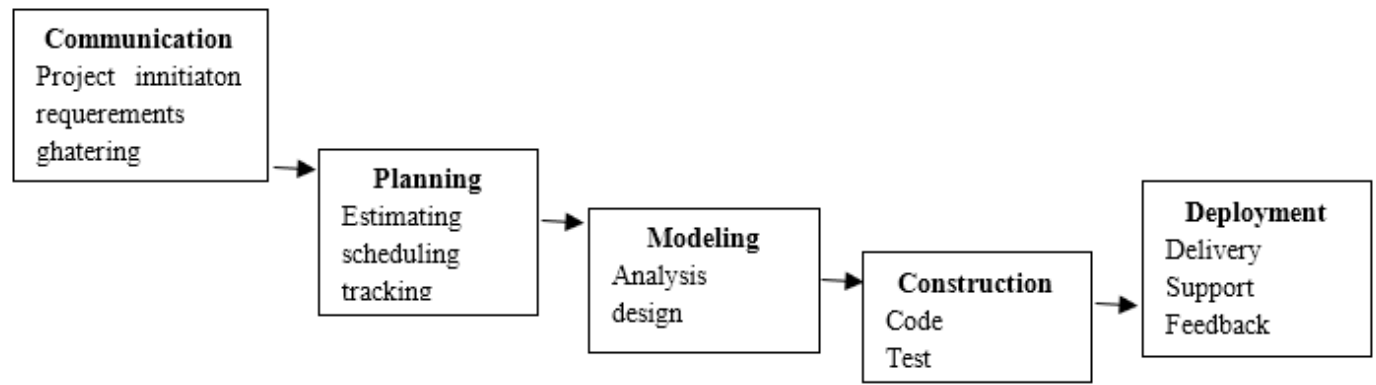

Figure 2. The Waterfall Step

From Figure 2 it can be seen that there are several steps [10]. The first step of the waterfall is communication. Communication is the first step in making a product by looking for data and information about the product by communicating with customers or consumers who will use the product. The second step of planning is the stage of planning to create software and the activities to be carried out by considering the possible risks. To make a product, we also have to make careful and precise planning to minimize the bad risks that may occur during the implementation of product manufacture, both from the schedule, the data needed, and how the product results will be made. The third step of modeling (Modeling) is designing a unified modeling language (UML) and user interface. The fourth step of construction (Construction) is making coding using a programming language for black box testing. Black box testing is used to test whether the device has responded to all commands given by the user or the user in running the application [11]. The fifth step is the delivery of the system to the customer/user (Deployment) which is the activity of providing the final product to the user. Regular checks and maintenance must always be carried out to maintain and ensure that the application continues to run properly.

The product test of this research consisted of a validity test, practicality test, and effectiveness test. The instrument used is a questionnaire.

\section{Results and Discussion}

To see the relationship between actors and the system, use case diagrams for the application design for calculating inheritance using the expected functionality of a system are used use case diagrams. Figure 3 below is a use case diagram of E-Mawaris. 


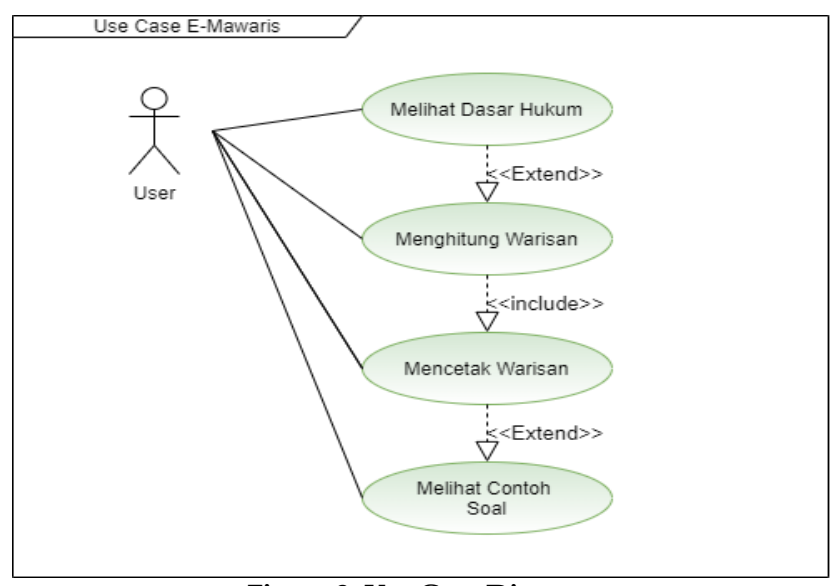

Figure 3. Use Case Diagram

Figure 4 is an activity diagram.

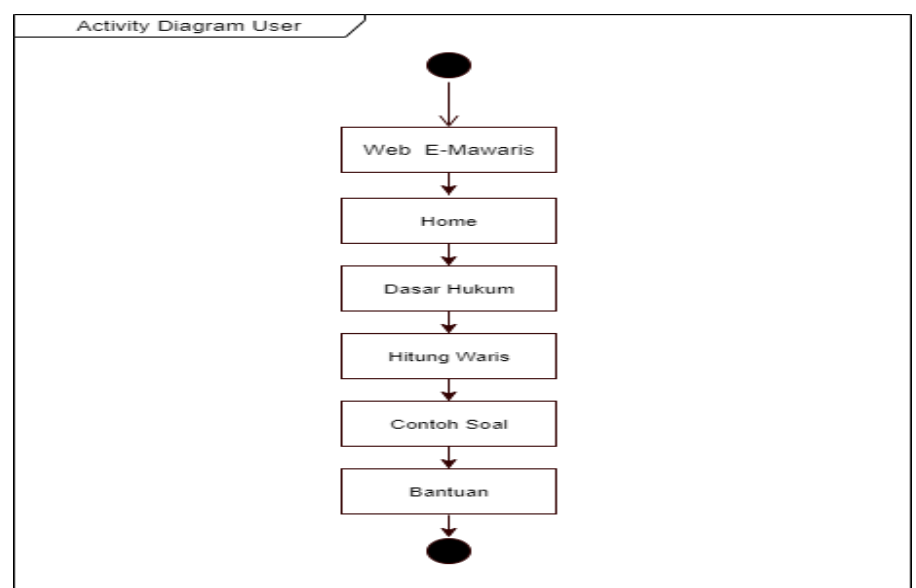

Figure 4. Activity Diagram

Figure 5 is a sequence diagram.

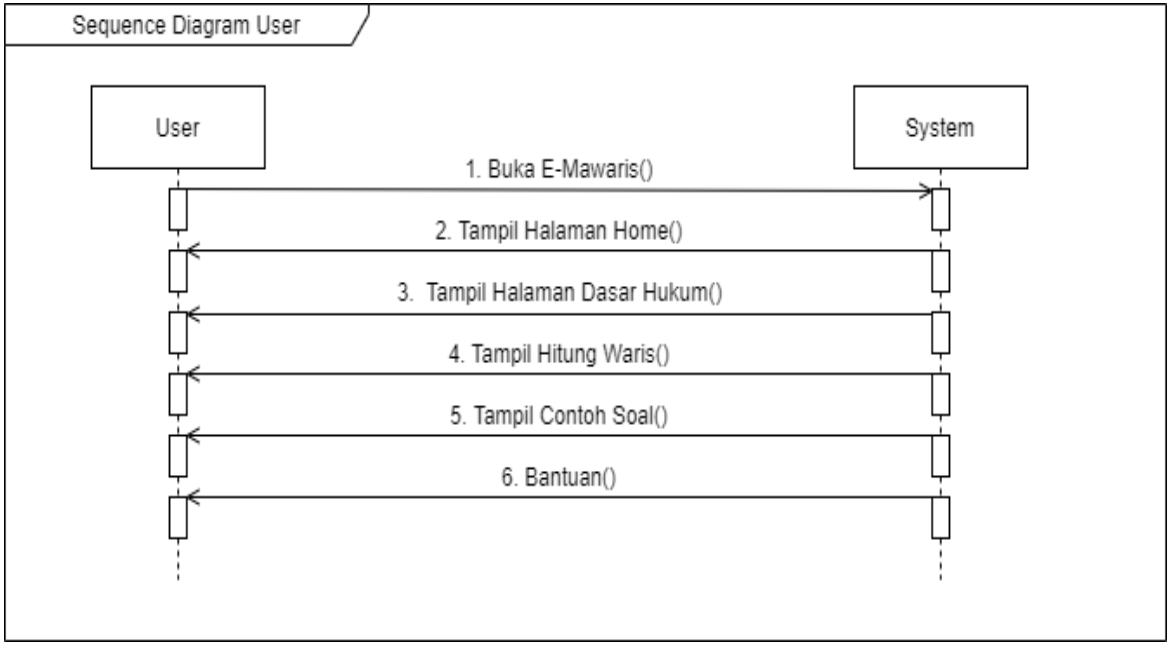

Figure 5. Sequence Diagram

Figure 6 is the initial view of the application. 


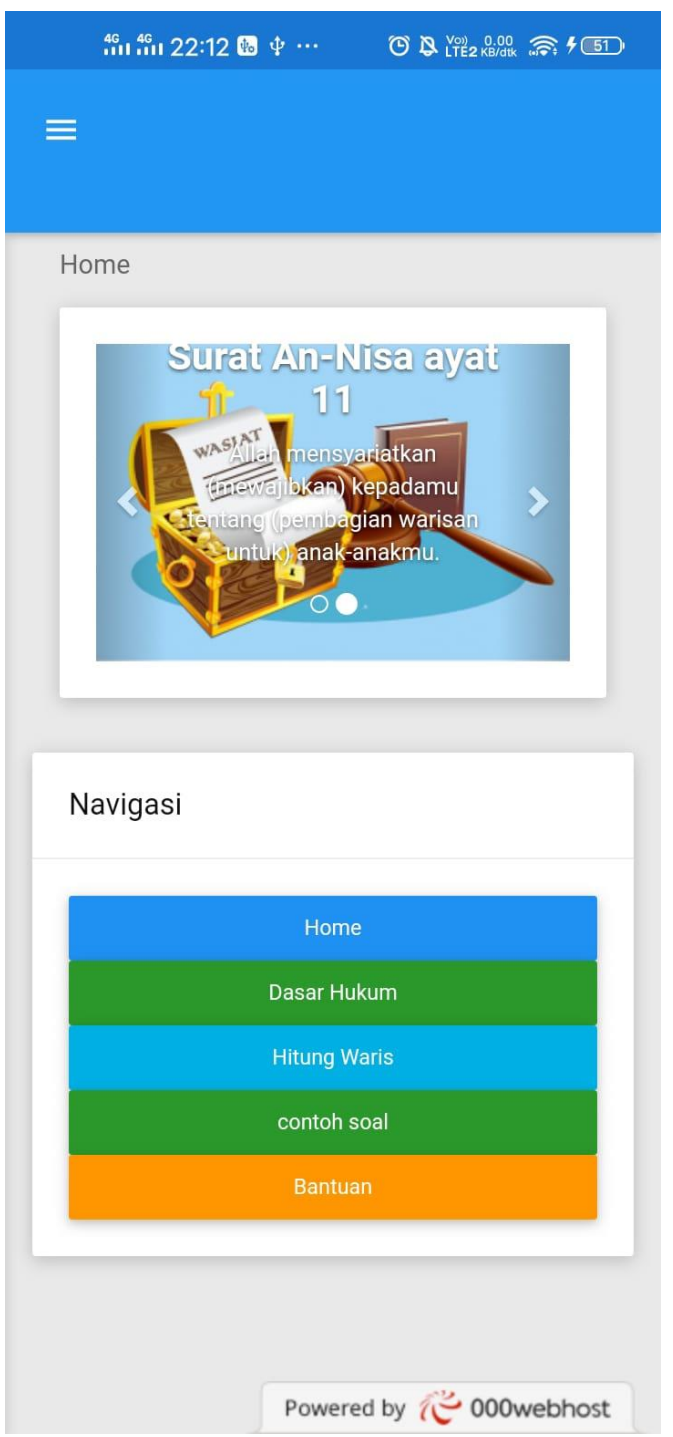

Figure 6. Initial Appearance of the Application

Figure 7 is the inheritance calculation process. 


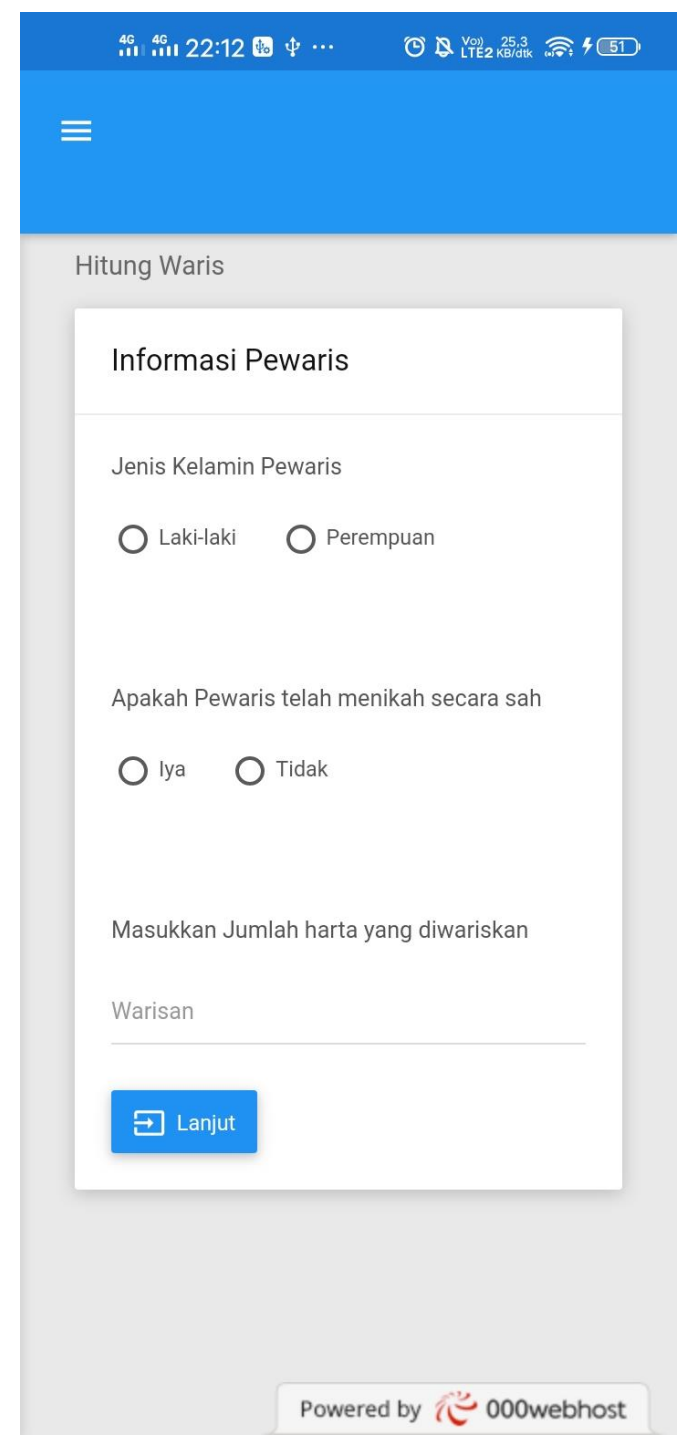

Figure 7. Inheritance Calculation

Figure 8 is an example of practice questions. 


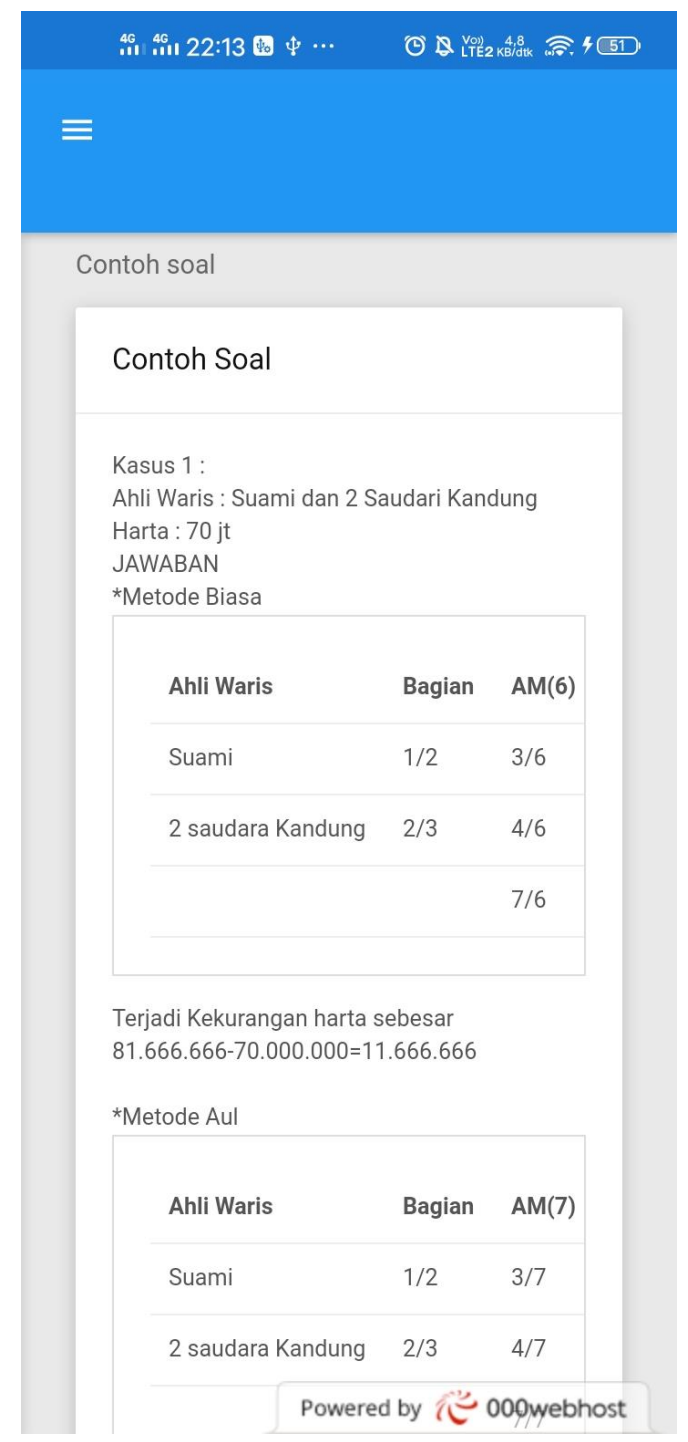

Figure 8. Example of Practice Questions

Listing of this application program can be seen as follows.

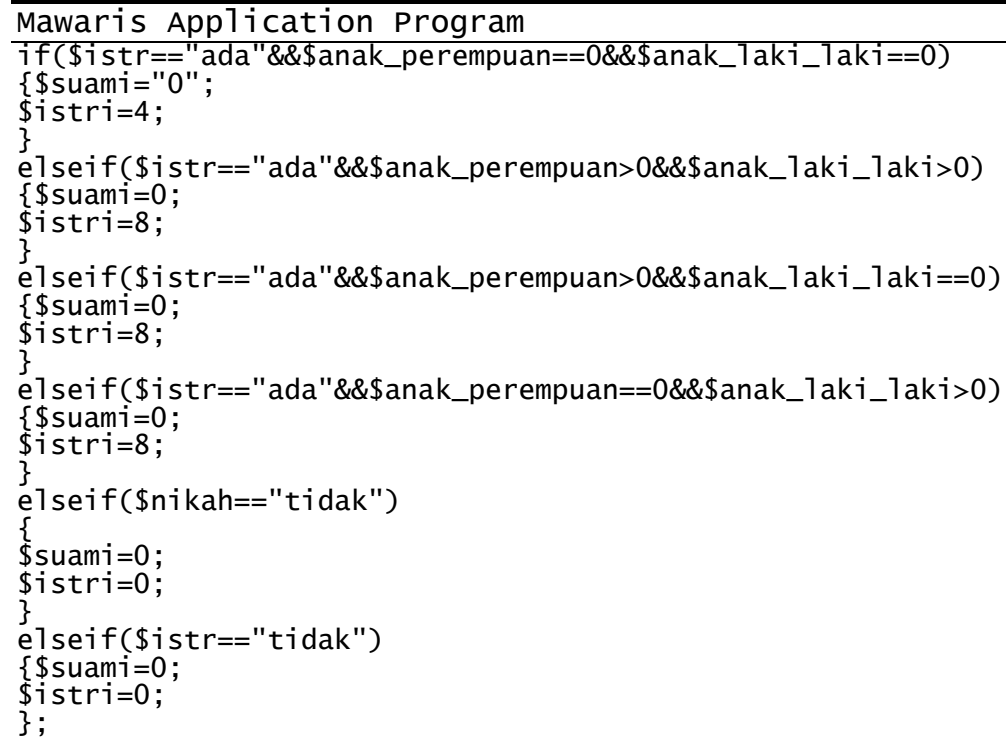


Based on the results of validity tests conducted on several experts, the results obtained were 0.80 , with valid criteria. Based on the results of the practicality test, a score of 96 was obtained, with the criteria of Very Practical. Based on the effectiveness test results, it can be obtained results with an average value of 0.86 , with a high effectiveness category.

\section{Conclusion}

Based on the research that the author has done, it can produce an inheritance counter application or EMawaris for the Mawaris Fiqh course at the Sharia Faculty IAIN Bukittinggi study program. This system is designed to make it easier to calculate inheritance quickly and with maximum results. In the research that the author is doing this time requires data and information that will later be processed as material in making the system, therefore a method is needed to obtain the data. In this study the author uses the R\&D development model is the $4 \mathrm{D}$ version. This model also makes it easier for authors to manufacture and develop products because the implementation of each activity is carried out sequentially. So that it makes it easier to design an inheritance calculation application according to Islamic law in the Mawaris fiqh course.

This system is designed using the PHP programming language using the MySQL database. With the help of several applications such as XAMP, Google Chrome, and sublime text text editor. This application gets a validation value of 0.80 , a practicality value of 0.96 , and an effectiveness value of 0.86 .

\section{References}

[1] A. R. Mariana, A. Budiman, and N. Septiana, “Sistem Informasi Aplikasi Penilaian Sidang Skripsi Berbasis Web di STMIK Bina Sarana Global,” J Sisfotek Glob, vol. 3, no. 2, pp. 18-22, 2013.

[2] Harmen, O. Pahlevi, and T. Santoso, "Aplikasi Perhitungan Pembagian Harta Warisan Dalam Islam Berbasis Web," J. Ris. Komput., vol. Vol 6 No 5, no. 5, pp. 460-469, 2016.

[3] J. Syariah and H. Islam, “No Title," vol. 1, pp. 93-107, 2018.

[4] N. K. Ceryna Dewi, I. B. G. Anandita, K. J. Atmaja, and P. W. Aditama, “Rancang Bangun Aplikasi Mobile Siska Berbasis Android," SINTECH (Science Inf. Technol. J., vol. 1, no. 2, pp. 100-107, 2018.

[5] A. Fatoni and N. Najmudin, "Revitalisasi Harta Waris Islam (Faraid) Dalam Perekonomian," Syi ar Iqtishadi J. Islam. Econ. Financ. Bank., vol. 3, no. 1, p. 48, 2019.

[6] R. Okra and Y. Novera, "Pengembangan Media Pembelajaran Digital IPA Di SMP N 3 Kecamatan Pangkalan," J. Educ. Educ. Student, vol. 4, no. 2, p. 122, 2019.

[7] H. T. Sutarti and I. Edi, Kiat-Kiat Sukses Meraih Hibah Penelitian Pengembangan. Yogyakarta: CV Budi Utama, 2017.

[8] R. Shalahuddin, “Rekayasa Perangkat Lunak Terstruktur dan Berorientasi Objek," JTIK, vol. 1, pp. 137-166, 2014.

[9] W. Nugraha, M. Syarif, and W. S. Dharmawan, "Penerapan Metode Sdlc Waterfall Dalam Sistem Informasi Inventori Barang Berbasis Desktop," JUSIM (Jurnal Sist. Inf. Musirawas), vol. 3, no. 1, pp. 22-28, 2018.

[10] P. Setiawan and Sulistiowati, "Rancang Bangun Aplikasi Pengolahan Data Evaluasi Proses Belajar Mengajar Berbasis Web," Jsika, vol. 4, no. 2, pp. 1-6, 2015.

[11] T. S. Jaya, "Pengujian Aplikasi dengan Metode Blackbox Testing Boundary Value Analysis (Studi Kasus: Kantor Digital Politeknik Negeri Lampung)," J. Inform. Pengemb. IT, vol. 3, no. 2, pp. 45-48, 2018. 